\title{
RANCANG BANGUN SISTEM INFORMASI PENGENDALIAN PERSEDIAAN (CONTROL BUFFER STOCK) UNTUK EFISIENSI KEWIRAUSAHAAN PENJUALAN KOPI PADA SOFT COFFEE
}

\author{
First Wanita $^{1)}$, Mashud ${ }^{2)}$, Randy Angriawan ${ }^{3)}$, dan Claudia Elma Pratiwi ${ }^{4)}$ \\ ${ }^{1,3)}$ Program Studi Teknik Informatika, STMIK AKBA \\ ${ }^{1,4)}$ Program Studi Sistem Informasi, STMIK AKBA \\ Jalan Perintis Kemerdekaan No. 75, Km. 9, Makassar \\ e-mail: firstwanita@akba.ac.id ${ }^{1)}$, mashud@akba.ac.id ${ }^{2}$, randy@akba.ac.id ${ }^{3)}$, claudiaelmapratiwi@gmail.com ${ }^{4)}$
}

\begin{abstract}
ABSTRAK
Tujuan penelitian ini untuk merancang dan mengimplementasikan sistem informasi Pengendalian Persediaan Kopi sebagai alat kontrol pembelian bahan baku dalam menjalankan kegiatan usaha agar berjalan secara efisien dan mampu menghasilkan laba yang optimal. Metode yang digunakan Buffer Stock, Reorder Point Dan Economic Order Quantity Pada Soft Coffee. Hasil pengujian Reorder Point (ROP) dan Safety Stock maka nilai ROP Kopi Arabika sebesar 21 Pak, Kopi Robusta sebesar 20 Pak, Kopi Liberika sebesar 22 Pak dan Kopi Ekselsa sebesar 21 Pak, sehingga dapat disimpulkan bahwa hasil perancangan sistem informasi pengendalian persediaan dapat diimplementasikan untuk efisiensi kewirausahaan penjualan kopi.
\end{abstract}

Kata Kunci: Kewirausahaan, Kopi, Pengendalian, Penjualan, Persediaan

\section{ABSTRACT}

The purpose of this study is to design and implement a coffee inventory control information system as a means of controlling the purchase of raw materials in carrying out business activities in order to run efficiently and be able to generate optimal profits. The method used is Buffer Stock, Reorder Point and Economic Order Quantity in Soft Coffee. The results of testing Reorder Point (ROP) and Safety Stock, the ROP value of Arabica coffee is 21 packs, Robusta coffee is 20 packs, Liberika coffee is 22 packs and Ekselsa coffee is 21 packs, so it can be concluded that the results of inventory control information system design can be implemented for entrepreneurial efficiency of coffee sales.

Keywords: Coffee, Control, Entrepreneurship, Inventory, Sales

\section{PENDAhUluan}

$\mathrm{P}$ engendalian merupakan upaya dari manajemen untuk mencapai tujuan yang telah direncanakan. Pengendalian dalam perusahaan sangat penting karena akan mempengaruhi kelancaran operasional yang secara tidak langsung juga berpengaruh terhadap keberhasilan dari perusahaan tersebut. Sistem pengendalian dalam kegiatan produksi adalah pengendalian proses produksi, pengendalian persediaan bahan baku, pengendalian tenaga kerja, pengendalian biaya produksi, pengendalian kualitas serta pemeliharaan.[1]

Persediaan merupakan barang-barang atau bahan baku yang diperlukan dalam proses produksi maupun digunakan untuk dijual dalam periode tertentu.[2]. Semakin besar bahan baku yang dibeli maka akan semakin besar biaya penyimpanan. Sebaliknya semakin kecil bahan baku yang dibeli semakin kecil biaya penyimpanannya. Salah satu model yang sering digunakan untuk mengetahui jumlah persediaan bahan baku adalah model EOQ (economic Order Quantity), Buffer Stock dan Reorder Point (ROP). Economic Order Quantity (EOQ) adalah ukuran yang memberikan biaya maksimum dalam membeli bahan baku dan secara keseluruhan memberikan kontribusi terhadap persediaan bahan pada tingkatan optimum dengan biaya minimum.[3]. Reorder Point (ROP) adalah tingkatan persediaan dimana ketika persediaan telah mencapai titik tersebut maka pemesanan ulang harus dilakukan. [4]. Sedangkan, Buffer Stock adalah persediaan tambahan yang mengizinkan terjadinya ketidaksamaan permintaan sebuah penyangga. Diharapkan Dari penggabungan ke dua metode tersebut pada sistem ini dapat membantu pihak manajemen sebagai alat kontrol persediaan dalam menjalankan kegiatan usaha agar berjalan secara efisien dan mampu menghasilkan laba yang optimal dengan membuat sebuah sistem yang dapat membantu menentukan jumlah Buffer Stock minima yang diperlukan untuk mencegah stock out sehingga dapat menentukan jumlah bahan baku yang dibutuhkan sehingga dapat tetap efisien dalam memenuhi permintaan costumer. 
Berdasarkan uraian diatas, peneliti memilih menggunakan EOQ karena perusahaan yang diteliti tidak memiliki banyak jenis persendiannya, selain itu, perusahaan yang diteliti juga masih dalam skala perkembangannya sehingga lebih cocok menggunakan model EOQ yang lebih sederhana.

Soft Coffee merupakan suatu usaha yang bergerak di bidang kuliner yang fokus pada penjualan minuman terutama kopi. Bahan baku utama yang digunakan dalam proses produksi adalah kopi house blend yaitu campuran antara kopi arabika dan kopi robusta dengan perbandingan $40 \%$ dan $60 \%$. Usaha ini berpusat di Jl. Kihajar Dewantara no, 16, Kecamatan Masamba.

\section{METODE PENELITIAN}

Jenis penelitian yang penulis gunakan adalah Research And Development (R\&D) saat ini merupakan salah satu jenis penelitian yang banyak dikembangkan. Penelitian ini merupakan salah satu jenis penelitian yang dapat menjadi penghubung atau pemutus kesenjangan antara penelitian dasar dengan penelitian terapan. Sering diartikan sebagai suatu proses atau langkah-langkah untuk mengembangkan suatu produk baru atau menyempurnakan produk yang telah ada.

Penelitian ini dilaksanakan di Soft Coffee Masamba yang terletak di Jl. Kihajar Dewantara no, 16, Kecamatan Masamba.

Perancangan sistem secara umum dapat dilihat pada flowchart dan UML diagram berikut ini:

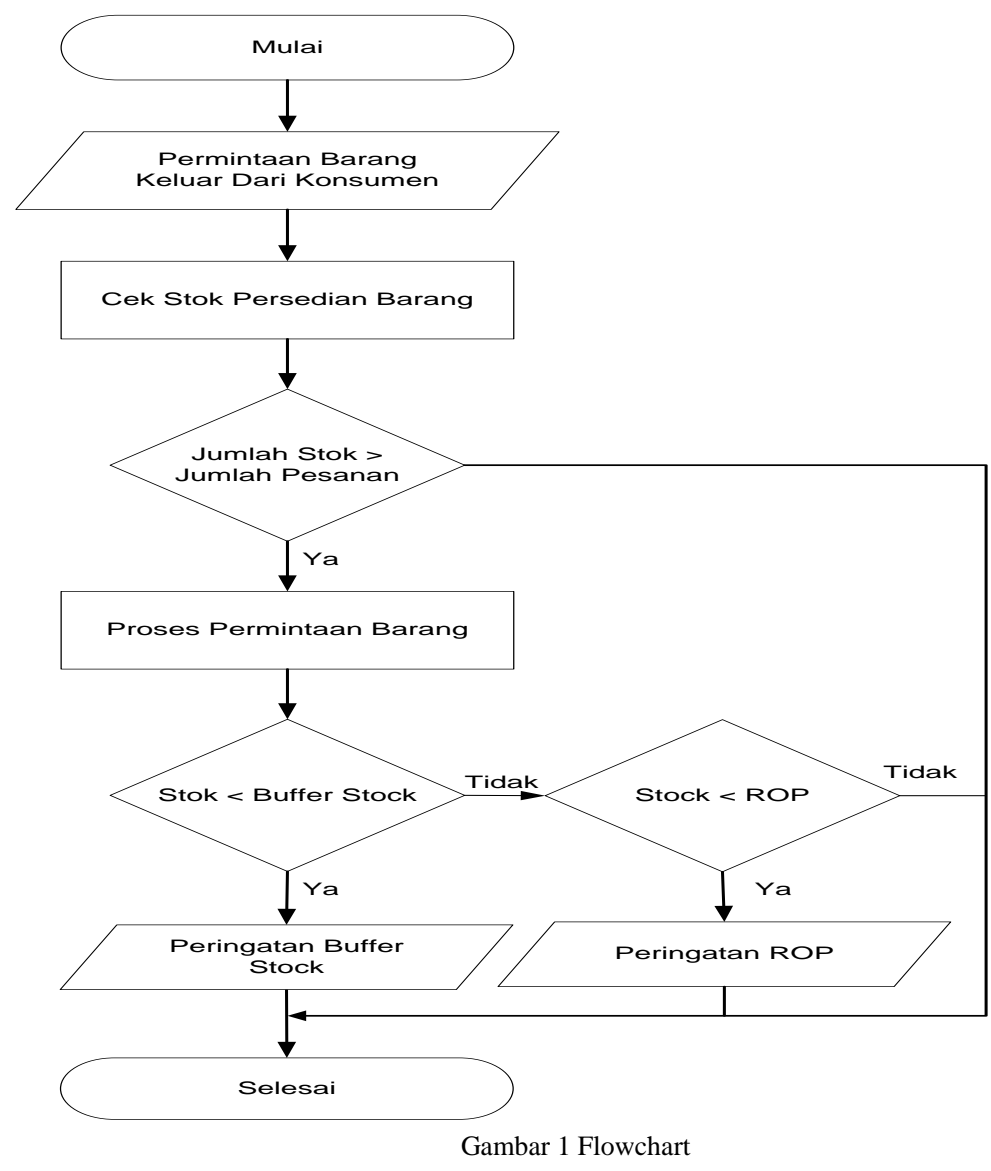




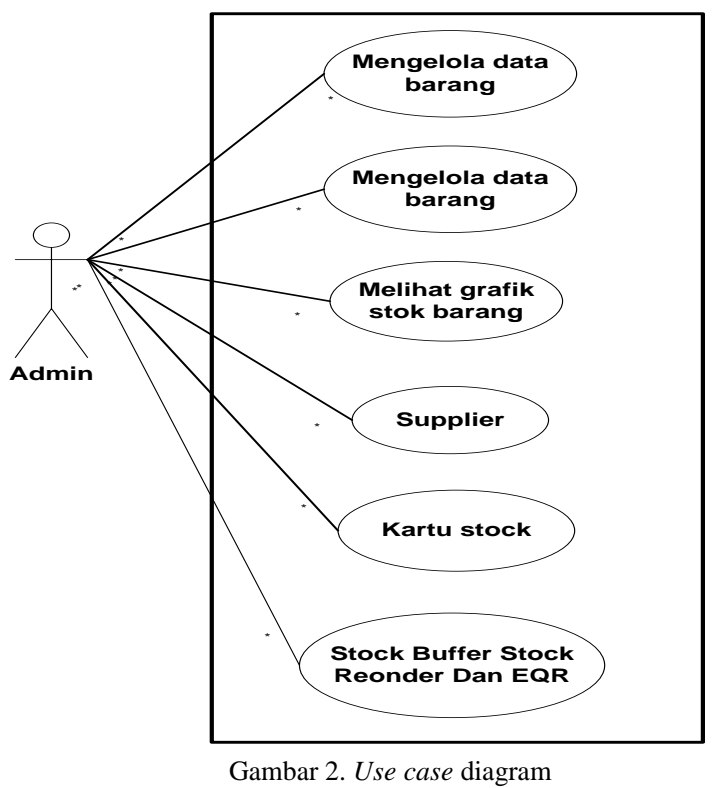

Gambar 2 merupakan use case diagram yang menjelaskan alur kerja sistem. Pada diagram tersebut obyek yang berinteraksi adalah admin, dimana admin mengelola barang keluar kemudian admin akan melihat grafik stok barang, setelah itu supplier akan memasukkan data barang kemudian admin mengecek kartu stok dan dapat melihat laporan stock buffer stock reorder dan EQR.

\section{LANDASAN TEORI}

\section{A. Pengendalian Persediaan}

Pengendalian adalah proses yang dilakukan dalam memastikan seluruh rangkaian kegiatan yang telah diimplementasikan dapat berjalan sesuai dengan rencana dan target yang diharapkan. Adapun Fungsi pengendalian merupakan upaya sitematis dalam menetapkan standar kinerja dan berbagai tujuan yang direncanakan, membandingkan standar yang telah dicapai dengan yang sudah ditetapkan sebelumnya, menentukan apakah terdapat sebuah penyimpangan, dan mengambil tindakan yang diperlukan untuk memastikan seluruh sumber daya perusahaan dipergunakan secara efisien dalam pencapaian tujuan perusahaan.[5]

\section{B. Bahan Baku}

Bahan baku adalah semua bahan yang digunakan dalam proses produksi perusahaan atau pabrik, kecuali terhadap bahan-bahan yang secara fisik akan digabungkan dengan produk yang dihasilkan oleh perusahaan atau pabrik tersebut. [6]

\subsection{Economic Order Quantity (EOQ)}

Metode economic order quantity yaitu jumlah pemesanan yang ekonomis. economic order quantity merupakan jumlah atau besarnya pesanan yang dimiliki jumlah ordering cost dan carriying cost per tahun yang paling minimal [6]

Economic Order Quantity adalah metode untuk menentukan kuantitas pesanan persediaan yang meminimumkan biaya penyimpanan dan biaya pemesanan [7]. Metode ini dapat digunakan baik untuk barangbarang yang diproduksi sendiri maupun barang dibeli dari supplier. Sedangkan menurut Heizer dan Render economic order quantity merupakan sebuah teknik kontrol persediaan yang meminimalkan biaya total dari pemesanan dan penyimpanan.[8]

Kesimpulannya metode economic order quantity merupakan metode yang digunakan untuk meminimalkan biaya pemesanan maupun penyimpanan guna untuk meminimalkan biaya yang dikeluarkan perusahaan.

Perhitungan EOQ dapat dilakukan dengan rumus sebagai berikut:

$$
E O Q=\frac{\sqrt{2 D S}}{h}
$$

Keterangan:

$\mathrm{S}$ : Biaya pemesanan per pesanan

D : Pemakaian bahan periode waktu 
$\mathrm{H}$ :Biaya penyimpanan per unit per tahun

\subsection{Safety Stock}

Dalam pemesanan suatu persediaan, perusahaan memerlukan waktu untuk menunggu persediaan itu datang. Hal ini biasa di sebut dengan Lead time atau waktu tunggu. Lead time adalah jangka waktu yang diperlukan sejak pemesanan sampai saat datangnya bahan baku yang dipesan [9]s. Untuk mengetahui lamanya lead time biasanya diketahui dari lead time pemesanan sebelumnya atau pengalaman sebelumnya. Adanya kemungkinan keterlambatan levansir dalam melakukan pengiriman bahan baku maka di perlukan adanya safety stock (persediaan pengaman).

Persediaan pengaman atau safety stock adalah persediaan tambahan yang diadakan untuk melindungi atau menjaga kemungkinan terjadinya kekurangan bahan baku. Akibat pengadaan persediaan pengaman dapat menambah biaya penyimpanan [6]

\subsection{Buffer Stock}

Buffer stock adalah persediaan tambahan yang diadakan untuk melindungi atau menjaga kemungkinan terjadinya kekurangan bahan (Stock Out). Pemesanan suatu barang sampai barang datang memerlukan jangka waktu yang bisa berbeda-beda setiap bulannya. Hal ini sering disebut dengan lead time. Lead time yang dimaksud adalah jangka waktu yang diperlukan sejak dilakukan pemesanan sampai saat datangnya bahan baku yang dipesan. Lead time diketahui dengan lead time pada histori atau pemesanan-pemesanan sebelumnya.

Safety Stock / persediaan pengaman ditentukan oleh manajemen dengan simbol :

$$
\text { SS }=\text { Safety Stock }
$$

\subsection{Re Order Point (ROP)}

Re Order Point (ROP) adalah saat atau titik dimana harus diadakan pemesanan lagi sedemikian rupa sehingga kedatangan atau penerimaan materials yang di pesan itu adalah tepat waktu dimana persediaan diatas safety stock sama dengan nol [10]. Faktor yang menentukan Reorder Point adalah:

1) Penggunaan materials selama tenggang waktu mendapatkan barang (procurement lead time)

2) Besarnya Reorder Point

$R O P=(L T x$ rata-rata penggunaan

bahan baku) + SS

Keterangan :

ROP : Reorder Point/Pemesanan Kembali

LT : Lead Time/Waktu Tunggu

SS : Safety Stock/Persediaan Pengamanan

\section{HASIL DAN PEMBAHASAN}

\subsection{Hasil Perancangan Sistem \\ 4.1. Home}

Home adalah halaman yang pertama kali tampil ketika user dan administrator membuka sistem monitoring persedian barang. Pada proses ini sistem sudah bisa menampilkan halaman utama seperti di gambar 3 .

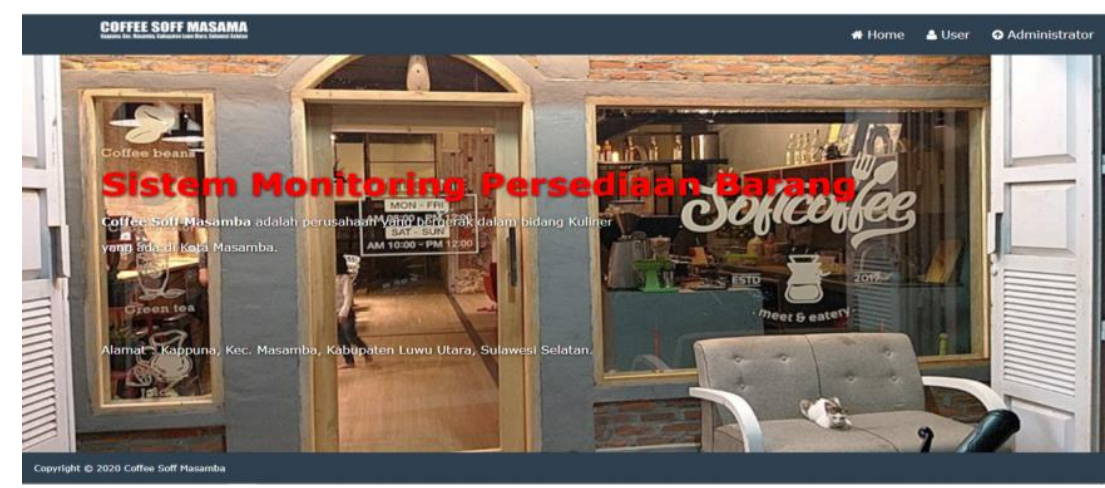

Gambar 3. Halaman Home 
Wanita, Mashud, Angriawan dan Pratiwi — Rancang Bangun Sistem Informasi Pengendalian Persediaan (Control Buffer Stock) Untuk Peningkatan Efisiensi Kewirausahaan Penjualan Kopi Pada Soft Coffee

\subsection{Login Administrator}

Login administrator adalah akses yang harus dilakukan oleh seorang admin untuk mengelola data barang, supplier dan kartu stok. Dibutuhkan validasi username dan password untuk mengakses login administrator. Pada proses ini sistem sudah bisa menampilkan halaman login seperti di gambar 4.

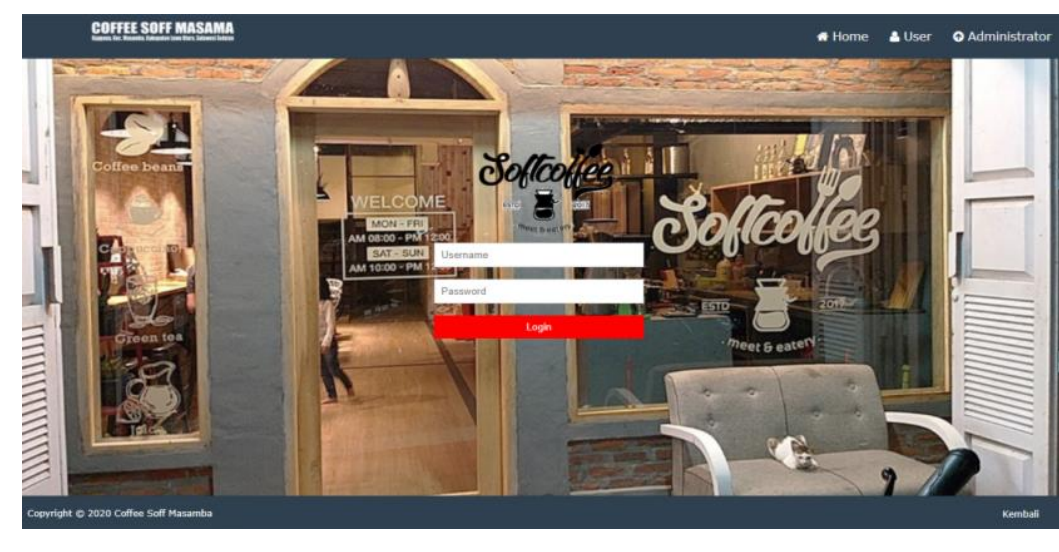

Gambar 4. Login Administrator

\subsection{Reorder Point dan Safety Stock}

Hasil login administrator adalah tampilan ketika administrator berhasil login. Pada proses ini sistem akan menampilkan status dari Reorder Point dan Safety Stock, pada proses ini sistem sudah bisa menampilkan hasil login administrator seperti di gambar 5 sistem menampilkan peringatan apabila stok telah melewati titik pemesanan kembali (ROP) dan batas aman persediaan barang.

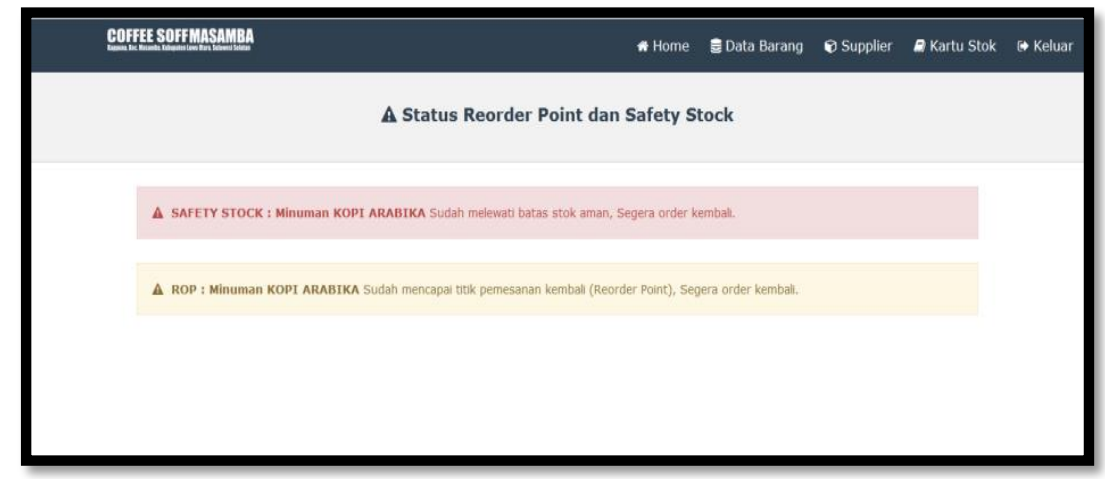

Gambar 5 Reorder Point dan Safety Stock

\subsection{Input Data Barang}

Input data barang adalah proses memasukkan data yang dilakukan oleh admin, Penggunaan per tahun adalah rata-rata pemakaian barang pada tahun sebelumnya, safety stock adalah cadangan persediaan, lead time adalah jangka waktu barang dipesan sehingga sampai ke soft coffee. Pada proses ini sistem sudah bisa menampilkan input data barang seperti di gambar 6 . 


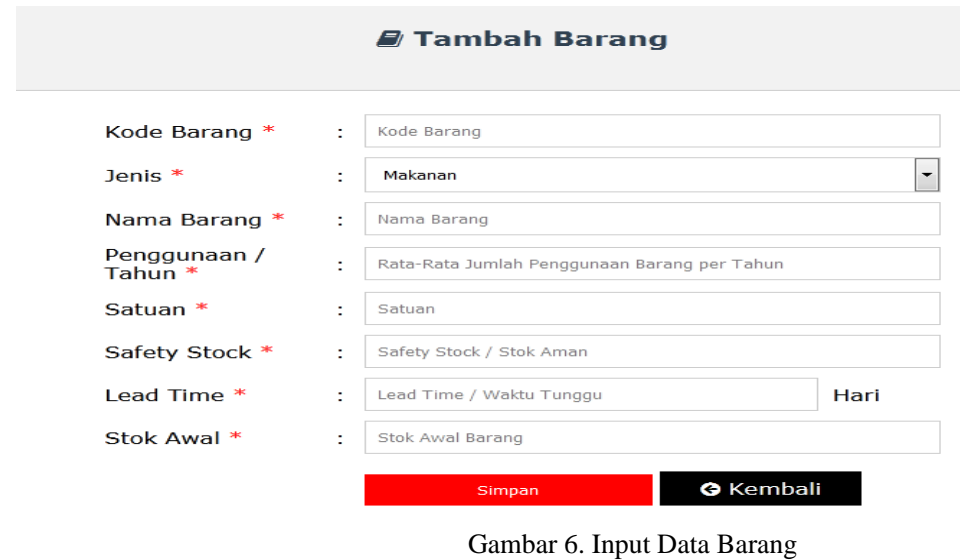

4.5. Data Barang

Data barang adalah detail data yang telah diinput sebelumnya, ROP dikalkulasi secara otomatis oleh sistem. Pada proses ini sistem sudah bisa menampilkan data barang yang sebelumnya dimasukkan seperti di gambar 7.

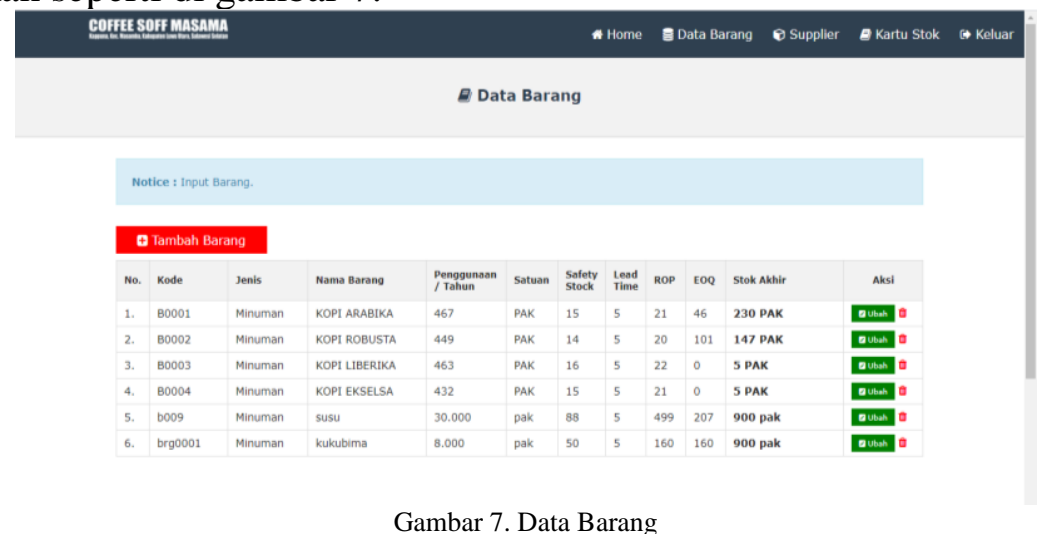

4.6. Input Supplier

Input supplier adalah menu untuk memasukkan data supplier, supplier adalah pemasok barang ke Soft Coffee. Pada proses ini sistem sudah bisa menampilkan input supplier seperti di gambar 8 .

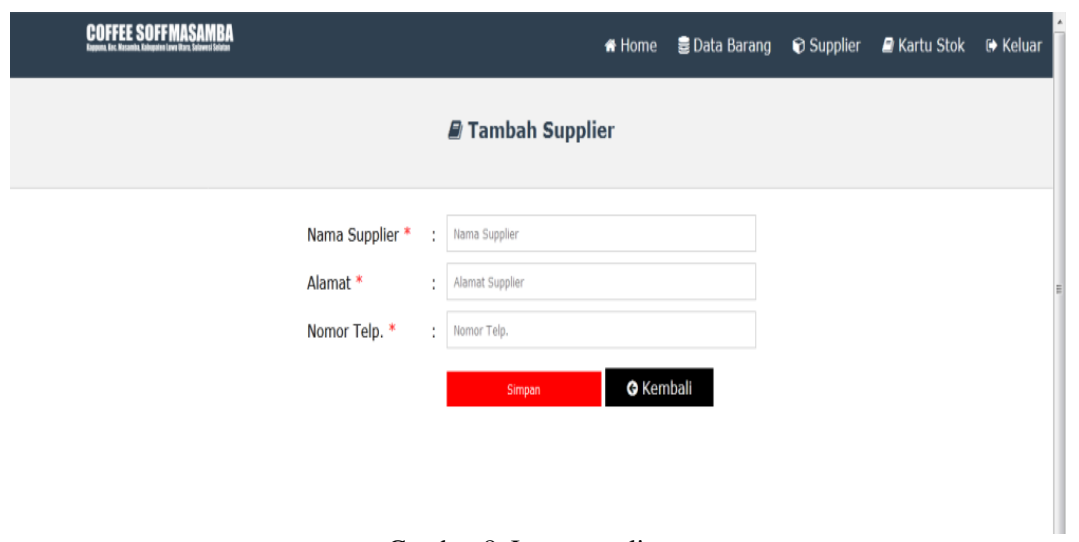

\subsection{Supplier}

Gambar 8. Input supplier

Pada proses ini sistem sudah bisa menampilkan daftar supplier yang telah dimasukkan seperti di gambar 9. 
Wanita, Mashud, Angriawan dan Pratiwi — Rancang Bangun Sistem Informasi Pengendalian Persediaan (Control Buffer Stock) Untuk Peningkatan Efisiensi Kewirausahaan Penjualan Kopi Pada Soft Coffee

\subsection{Kartu Stok Barang}

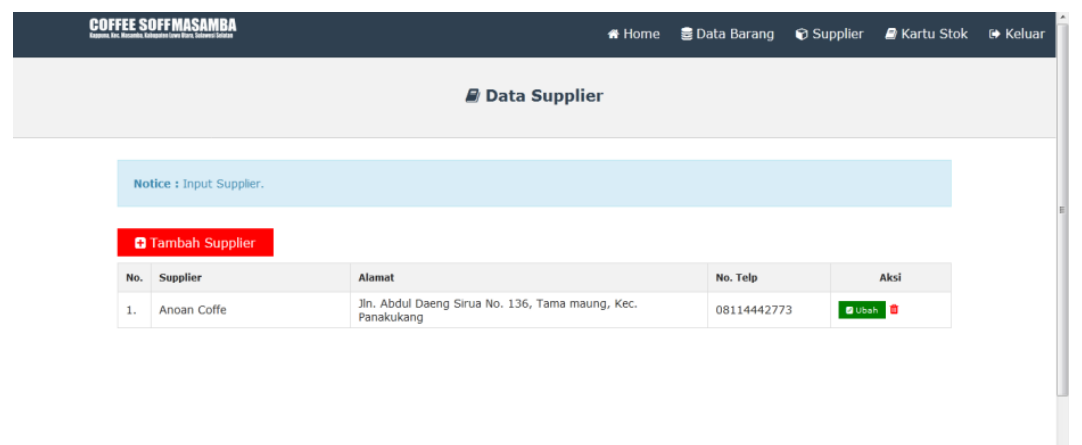

Gambar 9. Supplier

Kartu stok adalah rekapitulasi hasil penjumlahan proses barang masuk dan barang keluar, untuk melihat riwayat barang masuk dan barang keluar admin cukup memilih jenis kopi di combo box yang ingin dilihat riwayatnya. Pada proses ini sistem sudah bisa menampilkan kartu stok seperti di gambar 10.

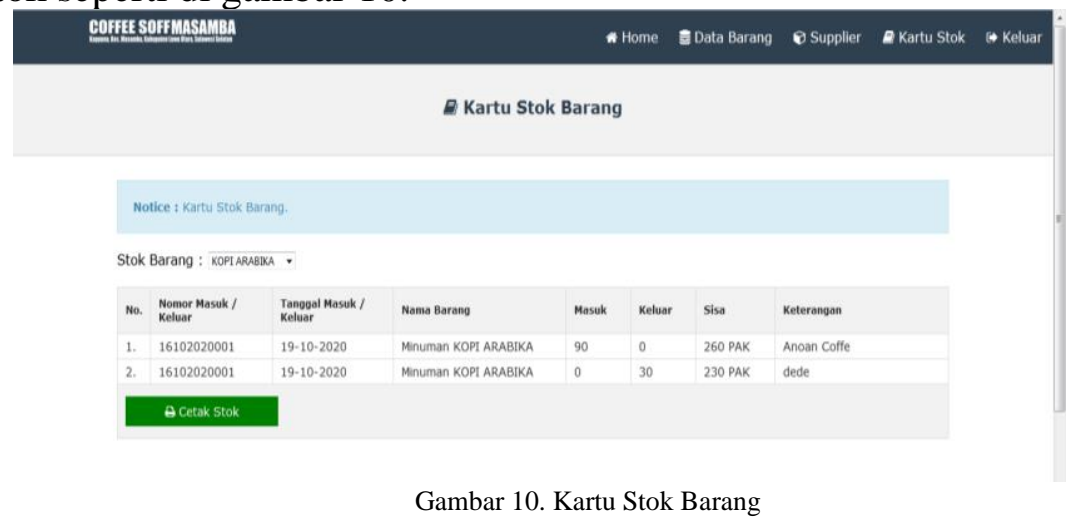

\subsection{Grafik Stok Barang}

Grafik stok barang adalah menu yang dapat diakses oleh user ketika berhasil login, sistem akan menampilkan grafik stok barang yang masih tersisa. Pada proses ini sistem sudah bisa menampilkan grafik stok barang seperti di gambar 11 .

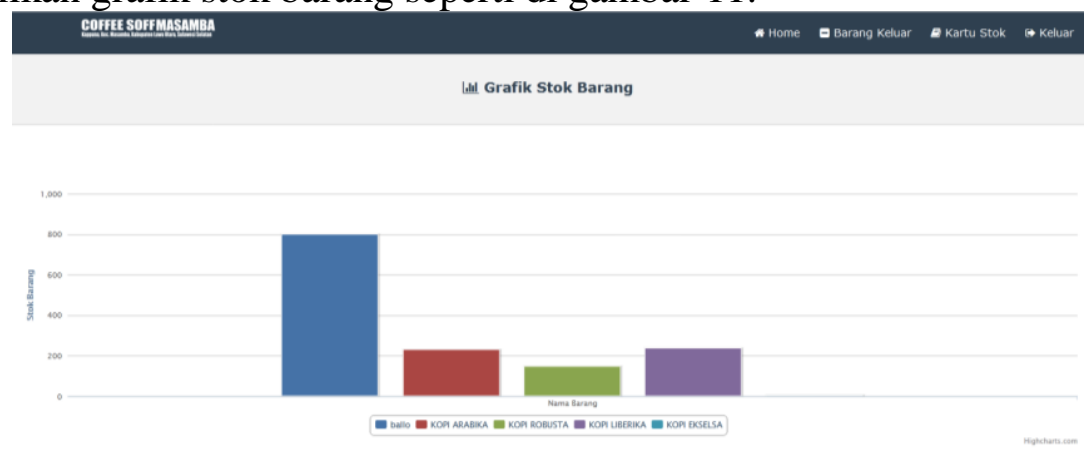

\subsection{Input Barang Keluar}

Input barang keluar adalah proses transaksi barang keluar. User memasukkan jumlah barang yang akan diproses oleh sistem, jika jumlah permintaan lebih besar dari stok maka sistem tidak akan melalukan proses permintaan barang. Pada proses ini sistem sudah bisa menampilkan proses transaksi barang keluar seperti di gambar 12. 


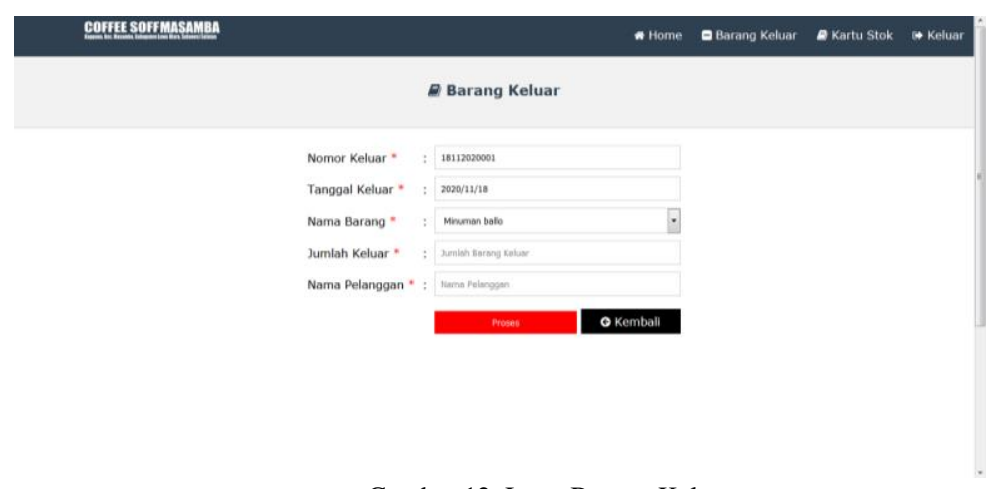

Gambar 12. Input Barang Keluar

\subsection{Barang Keluar}

Barang keluar adalah riwayat transaksi. Pada proses ini sistem sudah bisa menampilkan riwayat transaksi barang keluar seperti di gambar 13 .

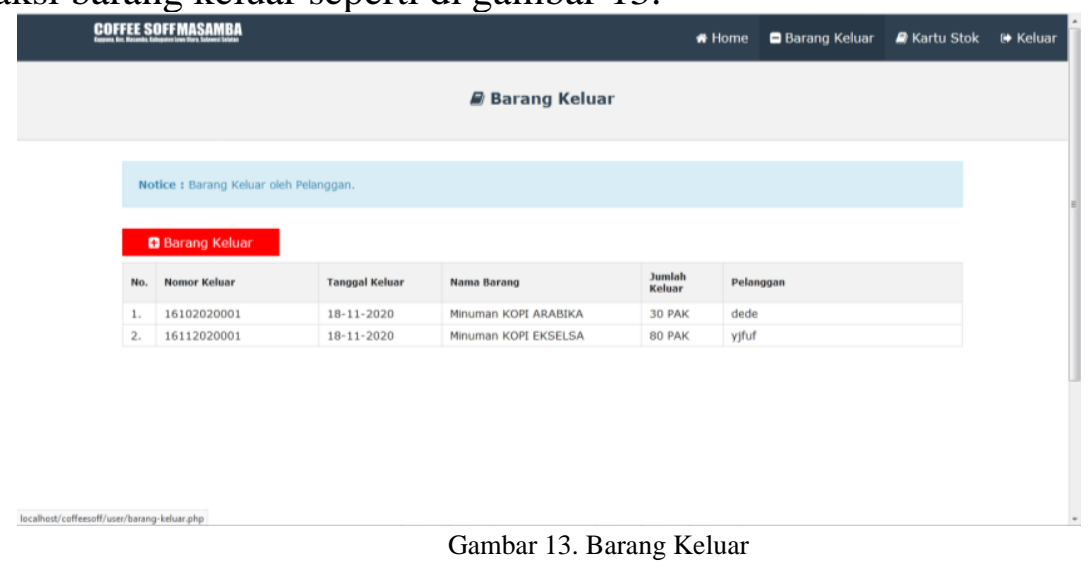

\subsubsection{Cetak Kartu Stok Barang}

Untuk melakukan pengendalian persediaan barang dibutuhkan tombol cetak. Pada proses ini sistem sudah bisa menampilkan cetak kartu barang seperti di gambar 14 .

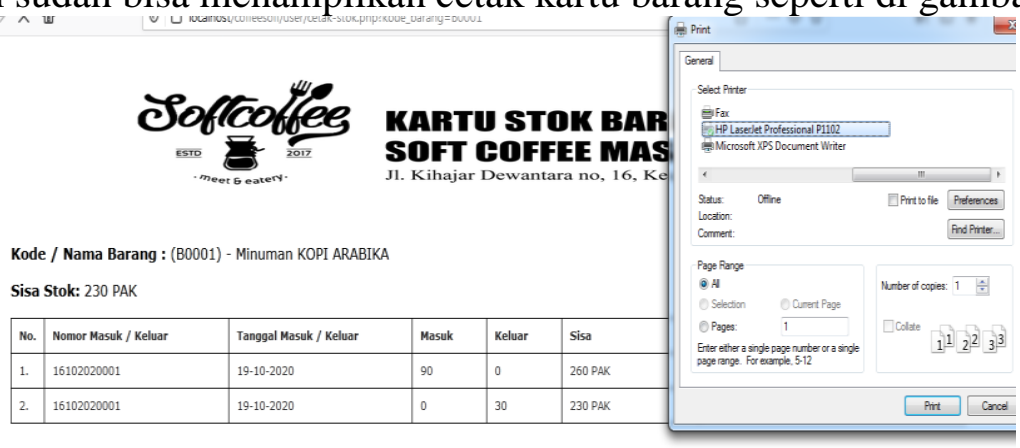

Gambar 14. Cetak Kartu Stok Barang

\subsection{Evaluasi Sistem}

Reorder Point (ROP) / titik pemesanan kembali 4 jenis kopi dapat dilihat pada table 1 .

Tabel 1. ROP Barang

\begin{tabular}{|l|c|c|c|c|c|}
\hline No & Nama Barang & $\begin{array}{c}\text { Safety } \\
\text { Stock }\end{array}$ & $\begin{array}{c}\text { Lead } \\
\text { Time }\end{array}$ & $\begin{array}{c}\text { Pemakaian } \\
\text { Rata-rata 2020 }\end{array}$ & ROP \\
\hline 1. & Kopi Arabika & 15 Pak & 5 Hari & 467 Pak & 21 Pak \\
\hline 2. & Kopi Robusta & 14 Pak & 5 Hari & 449 Pak & 20 Pak \\
\hline 3. & Kopi Liberika & 16 Pak & 5 Hari & 463 Pak & 22 Pak \\
\hline 4. & Kopi Ekselsa & 15 Pak & 5 Hari & 460 Pak & 21 Pak \\
\hline
\end{tabular}


Wanita, Mashud, Angriawan dan Pratiwi — Rancang Bangun Sistem Informasi Pengendalian Persediaan (Control Buffer Stock) Untuk Peningkatan Efisiensi Kewirausahaan Penjualan Kopi Pada Soft Coffee

\section{KESIMPULAN}

Berdasarkan hasil penelitian yang telah dilakukan dapat disimpulkan sebagai berikut :

1. Reorder Point (ROP) dapat digunakan untuk menentukan titik pemesanan kembali item dengan cara mengkombinasikan lead time, rata-rata pemakaian per periode, dan safety stock.

2. Berdasarkan hasil pengujian sistem maka nilai ROP Kopi Arabika sebesar 21 Pak, Kopi Robusta sebesar 20 Pak, Kopi Liberika sebesar 22 Pak dan Kopi Ekselsa sebesar 21 Pak, sehingga dapat disimpulkan sistem dapat di implementasikan untuk untuk efisiensi kewirausahaan penjualan kopi..

\section{PUSTAKA}

R. N. Baroroh, Pengendalian Kualitas Proses Produksi Beras Pada UD. Sumber Rejeki Sejati Jember. Jember: Universitas Jember, 2019. M. C. Tuerah, "Analisis Pengendalian Persediaan Bahan Baku Ikan Tuna Pada CV. Golden KK,” J. EMBA, vol. 2, no. 4, pp. 524-536, 2014. N. Novijanto, "Penentuan Jumlah Persediaan Bahan Baku Produk Tempe Dengan Metode Economic Order Quantity (EOQ)," Agrotek, vol. 4, no. 1, pp. 35-40, 2010

A. V Langke, I. D. Palandeng, and M. M. Karuntu, “Analisis Pengendalian Persediaan Bahan Baku Kelapa Pada PT. Tropica Cocoprima Menggunakan Economic Order Quantity,” vol. 6, no. 3, pp. 1158-1167, 2018.

T. E. dan K. S. Sule, Pengantar Manajemen. Jakarta: Kencana, 2010.

S. Assauri, Manajemen Produksi dan Operasi. Jakarta: FE UI, 2004.

T. H. Handoko, Dasar-Dasar Manajemen Produksi Dan Operasi, Edisi I. Yogyakarta: BPFE, 2000. Heizer, Manajemen Operasi, 9th ed. Jakarta: Salemba Empat, 2009.

A. Slamet, Penganggaran Perencanaan dan Pengendalian Usaha. Semarang: UNNES PRESS, 2007.

B. Riyanto, Dasar-dasar Pembelanjaan Perusahaan, 5th ed. Yogyakarta: BPFE, 2001. 
JTIULM - Volume 6, Nomor 1, Bulan April: 9 - 18 